\title{
Two new species of Philometra (Nematoda: Philometridae) from needlefishes (Belonidae) in Iraq, with a key to Philometra spp. parasitic in the host's subcutaneous tissue, fins and musculature
}

\author{
František Moravec $^{1}$ and Atheer Hussain Ali $^{2}$ \\ ${ }^{1}$ Institute of Parasitology, Academy of Sciences of the Czech Republic, Branišovská 31, 37005 České Budějovice, Czech \\ Republic; \\ ${ }^{2}$ Department of Fisheries and Marine Resources, College of Agriculture, Basrah University, Basrah, Iraq
}

Key words: parasitic nematode, Philometra, marine fish, Strongylura, Tylosurus, Persian Gulf, Iraq

\begin{abstract}
Two new nematode species, Philometra strongylurae sp. n. and Philometra tylosuri sp. n., are described from female specimens collected from needlefishes (Belonidae, Beloniformes) off the Fao coast, Basrah, Persian Gulf, in Iraq. Philometra strongylurae (gravid females with larvae) was recorded from the subcutaneous tissue, muscles of beak and gills of Strongylura leiura (type host) and S. strongylura, whereas P. tylosuri (nongravid females) from the musculature and the subcutaneous tissue of Tylosurus crocodilus. The former is characterized mainly by the presence of eight markedly large cephalic papillae, conspicuously large anterior oesophageal bulb and by the length of body $(15-20 \mathrm{~mm})$; the latter by eight minute cephalic papillae, poorly developed oesophageal bulb and by the body length $(46-72 \mathrm{~mm})$. A key to Philometra spp. with gravid females parasitic in the subcutaneous tissue, fins or musculature of fishes is provided.
\end{abstract}

Parasitological examinations of three species of marine fishes, the banded needlefish Strongylura leiura (Bleeker, 1850), the spottail needlefish Strongylura strongylura (van Hasselt, 1823) and the hound needlefish Tylosurus crocodilus (Péron et Lesueur, 1821) (all Belonidae, Beloniformes) from off the Fao coast (Persian Gulf) in southern Iraq, carried out by the junior author (A.H. Ali) in 2002-2004, revealed the presence of female nematodes of the genus Philometra Costa, 1845 representing two new species. These are described herein.

\section{MATERIALS AND METHODS}

Fishes were deep-frozen after capture and were dissected in the laboratory; the skin was removed to reveal the parasites. Nematodes recovered were washed in physiological saline, fixed in Berland's fluid (19 parts pure glacial acid, 1 part 40\% formaldehyde solution), and stored in $70 \%$ ethanol. For light microscopical examination, they were cleared with glycerine. Drawings were prepared with the aid of a Zeiss microscope drawing attachment. After examination, specimens were stored in $70 \%$ ethanol. Two specimens of each species (complete specimens or body fragments) were also used for scanning electron microscopy. Nematodes were transferred to $4 \%$ formaldehyde solution and postfixed in $1 \%$ osmium tetroxide, dehydrated through a graded ethanol series, critical point dried and sputter-coated with gold; they were examined using a JEOL JSM-6300 scanning electron microscope at an accelerating voltage of $15 \mathrm{kV}$. All measurements are in micrometres unless otherwise stated. Scientific names of fishes follow Froese and Pauly (2004). Since many specimens of Philometra recovered from needlefishes were unidentifiable to spe- cies because of their poor condition and because more members of Philometra may occur in the same fish host species, data could not be interpreted to provide prevalence and intensity of infection.

\section{RESULTS}

Philometra strongylurae sp. n.

Figs. 1, 2

Description of gravid female (4 specimens; measurements of holotype in parentheses; measurements of 2 additional subgravid females in square brackets): Body of live specimens red, that of fixed specimens greyish, with distinctly visible light-brown intestine. Body cylindrical, 15.71-20.05 (20.05) [10.09 and 10.85] mm long, somewhat tapering at both ends; posterior part somewhat narrower than anterior part; maximum width of body 666-925 (884) [571 and 625] at region of oesophagus, width of cephalic end 204-299 (286) [231 and 258], of caudal end 204-231 (204) [190 and 204]. Ratio of maximum body width and overall length of body 1:17-24 (1:23) [1:11 and 1:19]. Cuticle smooth. Cephalic end blunt, wide, provided with marked cephalic papillae and pair of small lateral amphids. Mouth slightly depressed, oral aperture large, almost circular, surrounded by four pairs of large oval papillae arranged in one circle; two papillae subdorsal, two subventral, two dorsolateral and two ventrolateral. Anterior end of oesophagus forming conspicuous, strongly muscular, mostly transverse bulb, well separated from posterior cylindrical portion of oesophagus; bulb 136-218 (218) [136 and 136] long and 150-286 (272) [204 and 218] wide, anteriorly forming conspicuous lobes. Long 


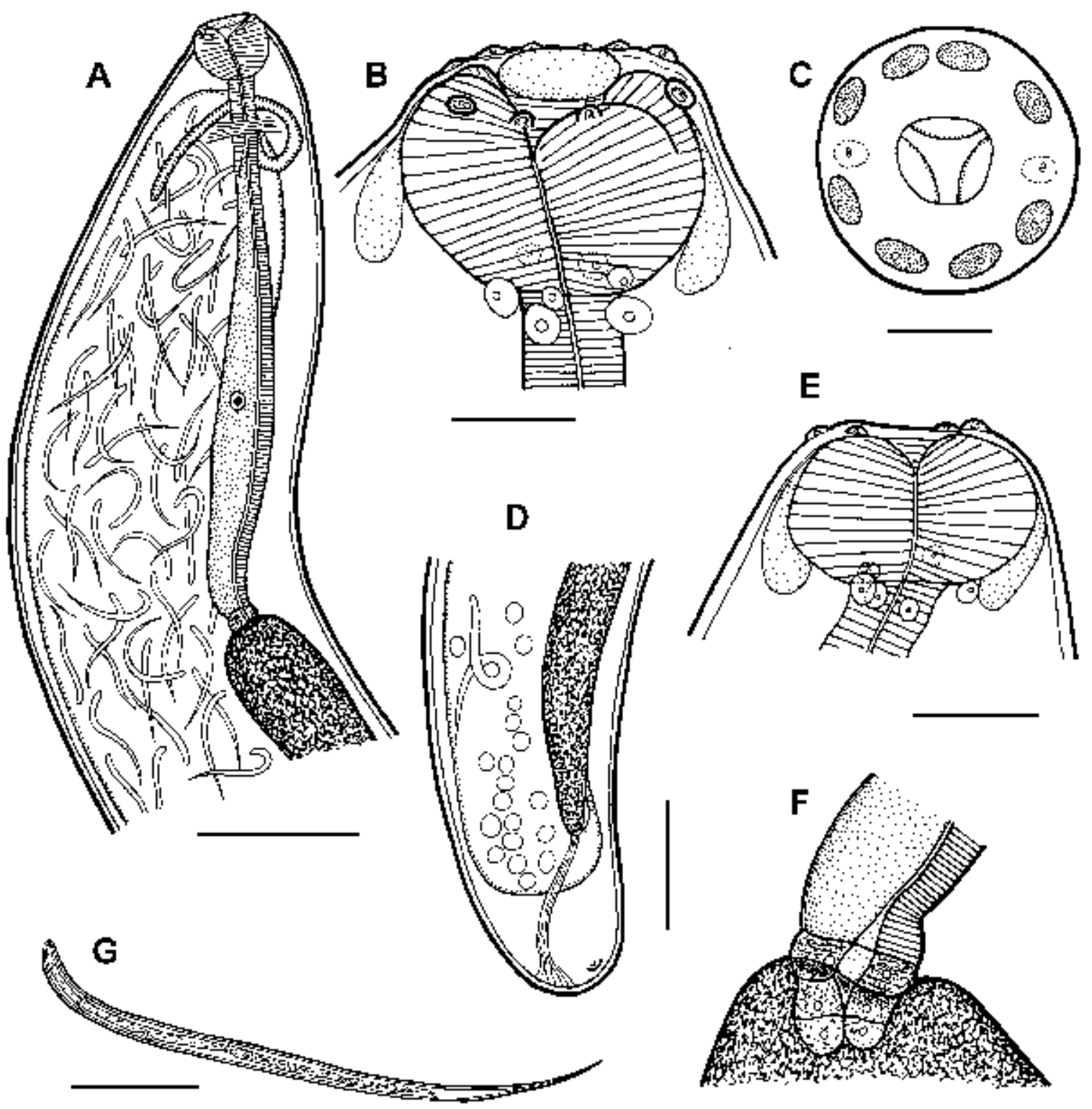

Fig. 1. Philometra strongylurae sp. n., female. $\mathbf{A}$ - anterior end of body of gravid specimen; $\mathbf{B}, \mathbf{C}$ - cephalic end, lateral and apical views; D - posterior end, lateral view; $\mathbf{E}$ - cephalic end of subgravid specimen; F - oesophago-intestinal junction; $\mathbf{G}$ - larva from uterus. Scale bars: $\mathrm{A}=500 \mu \mathrm{m} ; \mathrm{B}, \mathrm{C}, \mathrm{E}-\mathrm{G}=100 \mu \mathrm{m} ; \mathrm{D}=200 \mu \mathrm{m}$.

posterior portion of oesophagus almost cylindrical, provided with well-developed, wide oesophageal gland extending anteriorly just posterior to level of nerve ring; oesophageal gland containing large cell nucleus located somewhat posterior to its middle, at $(1,265)$ from anterior extremity in holotype. Overall length of oesophagus including anterior bulb 1.49-2.04 (2.04) [0.925; entire oesophagus indistinct in 1 specimen] $\mathrm{mm}$, representing 9-11\% (10\%) [9\%] of body length; maximum width of cylindrical part including oesophageal gland 109-150 (150) [82]. Small ventriculus present, (27) long and (82) wide in holotype, opening into intestine through valve. Nerve ring 272-340 (326) [218] from anterior end of body. Intestine broad, becoming narrower only near posterior end; posterior end of intestine atrophied, forming short translucent ligament attached ventrally to body wall near posterior extremity. Posterior end of body somewhat narrowed, rounded, with pair of poorly developed subdorsal papilla-like caudal projections. Anterior ovary short, reaching anteriorly nearly to base of oesophageal bulb, posterior ovary reaching to level of intestinal ligament. Uterus occupying major part of body, filled with numerous larvae (495-519) long and (18) wide $(\mathrm{n}=5)$; length of their oesophagus (171-183), of tail (111-144).

Male: Unknown. 

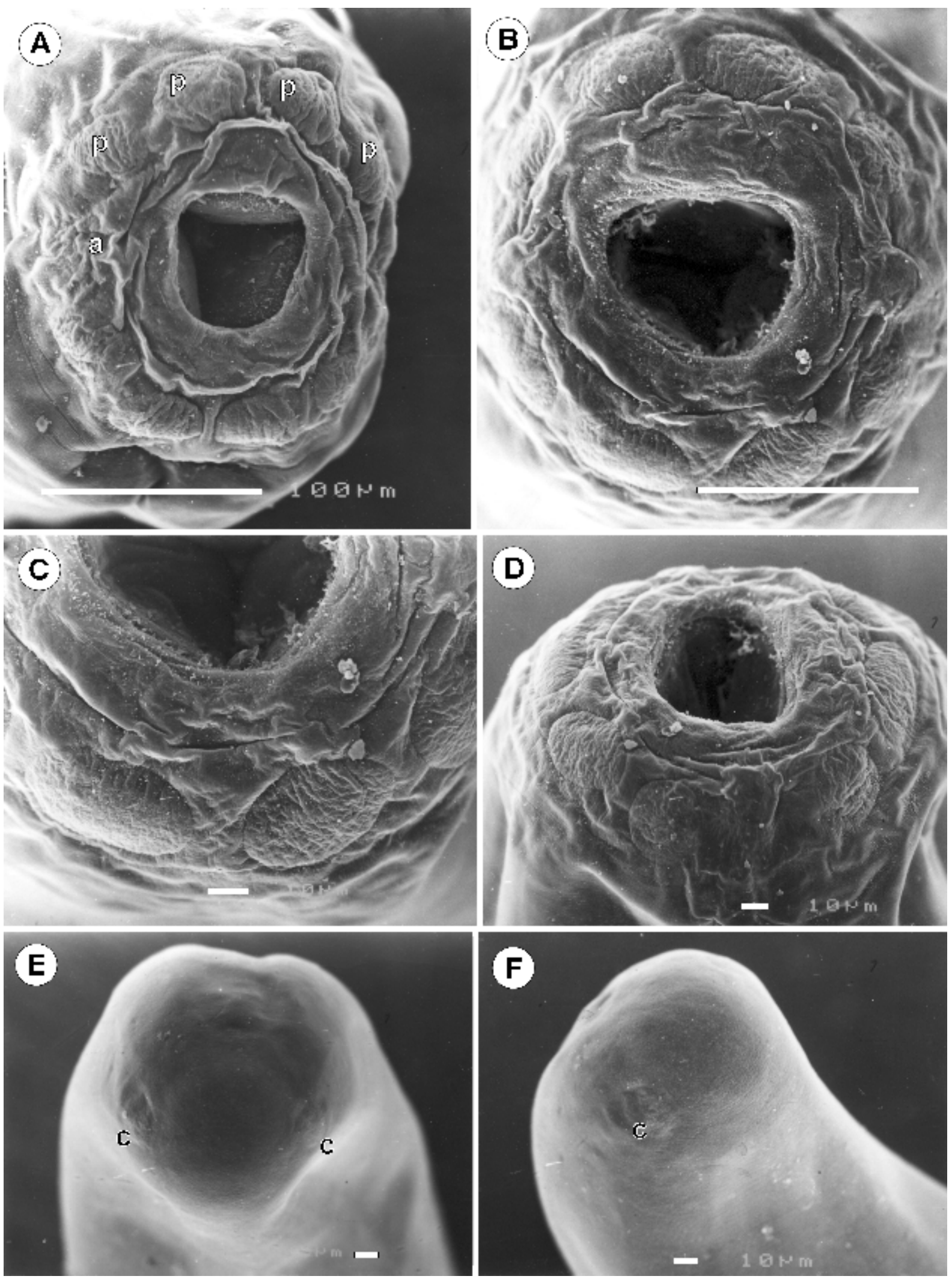

Fig. 2. Philometra strongylurae sp. n., scanning electron micrographs of gravid female. A - cephalic end, apical view; $\mathbf{B}-$ same, another specimen with different shape of oral aperture; $\mathbf{C}$ - detail of subventral cephalic papillae; $\mathbf{D}$ - cephalic end, sublateral view; E, F - caudal end, apical and lateral views. Abbreviations: a - amphid; c - caudal projection; $\mathrm{p}$ - cephalic papilla. Scale bars: $\mathrm{B}=100 \mu \mathrm{m} ; \mathrm{E}=10 \mu \mathrm{m}$ 
T y p e h o s t : Banded needlefish Strongylura leiura (Bleeker, 1850) (Belonidae, Beloniformes).

$\mathrm{O}$ t h e $\mathrm{r}$ h o s t : Spottail needlefish Strongylura strongylura (van Hasselt, 1823).

Site of infection: Subcutaneous tissue, muscles of beak, gills.

T y p e 1 o c a 1 i t y : Off Fao coast, Basrah $\left(28^{\circ} 55^{\prime} \mathrm{N}\right.$, $48^{\circ} 28^{\prime} \mathrm{E}$ ), Persian Gulf, southern Iraq (holotype collected 17 January 2004).

De position of types: Holotype and paratypes in the Helminthological Collection of the Institute of Parasitology, ASCR, in České Budějovice (cat. no. N-834).

$\mathrm{E} t \mathrm{y} \mathrm{molog} \mathrm{y}$ : The name of this nematode is derived from the generic name of its fish hosts.

\section{Philometra tylosuri sp. n.}

Figs. 3, 4

Description of nongravid female ( 2 complete and 2 incomplete specimens; measurements of holotype in parentheses): Body whitish, filiform, long, tapering slightly at both ends. Body length 46.72-72.39 (46.72) $\mathrm{mm}$, maximum width at level of oesophagus end 313571 (313); posterior part of body somewhat narrower than anterior part; width of cephalic end 54-109 (54), of posterior end of body 39-68 (39). Ratio of maximum width and overall length of body 1:127-149 (1:149). Cuticle smooth. Cephalic end rounded, separated from rest of body by slight transverse constriction (groove). Oral aperture small, circular, surrounded by minute cephalic papillae arranged in four submedian pairs in one circle, indistinct in lateral view; pair of small lateral amphids present. Three small oesophageal lobes distinctly protruding out from oral aperture. Oesophagus somewhat swollen at anterior end to form slight cephalic bulb 51-54 (54) long and 48-57 (57) wide, not separated from posterior cylindrical part. Overall length of oesophagus including anterior bulb 1.63-1.65 (1.65), representing $2.3-3.5 \%(3.5 \%)$ of whole body length; maximum width of posterior part of oesophagus (including oesophageal gland) 136-177 (136). Dorsal oesophageal gland prominent, wide, extending anteriorly to short distance below level of nerve ring; it contains large cell nucleus located at its middle, $(1,074)$ from anterior extremity in holotype. Small ventriculus present, (21) long and (51) wide in holotype, opening into intestine through large valve. Nerve ring 163-177 (163) from anterior extremity. Intestine light-coloured, straight, narrow, ending in long, colourless ligament attached to body wall. Posterior end of body somewhat narrowed, truncated or rounded, with two small poorly developed lateral papilla-like caudal projections. Ovaries reflected, near ends of uterus; posterior ovary markedly broad, straight. Larvae or eggs not yet present in uterus.

Male: Unknown.

$\mathrm{T}$ y $\mathrm{p}$ e $\mathrm{h}$ o s t : Hound needlefish Tylosurus crocodilus (Péron et Lesueur, 1821) (Belonidae, Beloniformes).
S ite of infection: Musculature and subcutaneous tissue.

T y p e 1 o c a 1 i t y : Off Fao coast, Basrah $\left(28^{\circ} 55^{\prime} \mathrm{N}\right.$, $\left.48^{\circ} 28^{\prime} \mathrm{E}\right)$, Persian Gulf, southern Iraq (holotype collected 28 September 2002).

Deposition of ty pes: Holotype and paratypes in the Helminthological Collection of the Institute of Parasitology, ASCR, in České Budějovice (cat. no. N-835).

E t y m o log y: The specific name of this nematode is derived from the generic name of its fish host.

\section{DISCUSSION}

The genus Philometra s.s. includes a large number of species parasitic in the abdominal cavity or in various body tissues of freshwater, brackish-water and marine fishes. Since minute males of most species remain unknown, the present identification of species is principally based on the female morphology (Rasheed 1963, Ivashkin et al. 1971, Moravec 2004). However, the morphology of females is rather uniform, not providing many features for distinguishing the species, which makes the identification difficult. Moreover, many species are poorly described, because females are sensitive to osmotic pressure and quickly burst in water and often only damaged specimens or body fragments are available to study. In addition to morphological features, data on the site of localisation of gravid females in the host's body are important for the identification of philometrids (Moravec and Rohde 1992, Moravec et al. 2002, 2004).

The following 10 species of Philometra, the gravid females of which are parasitic in the host's subcutaneous tissues or/and fins, are considered valid: P. bagri (Khalil, 1965) Moravec et Nagasawa, 1989, P. beninensis Obiekezie, 1986, P. kohnae Moravec et Rohde, 1992, P. lomi Moravec et Rohde, 1992, P. oreoleucisci Moravec et Ergens, 1970, P. pinnicola (Yamaguti, 1935) Yamaguti, 1941, P. plotosi Moravec et Nagasawa, 1989, P. rischta Skryabin, 1923, P. sebastodis Yamaguti, 1941, and P. sydneyi Rasheed, 1963. No valid species of Philometra has been reported from the host's musculature.

Differences between the two new species, Philometra strongylurae and $P$. tylosuri, and other, above-mentioned congeneric species with the same or similar localisation of gravid females in the host, are apparent from the following key.

Key to Philometra spp. with gravid females parasitic in fish subcutaneous tissues, fins and musculature:

1 Posterior end of body of gravid female with two large caudal protrusions. Cephalic end with four large, fleshy protrusions or papillae. Parasites of freshwater fishes ...................................... 2

- Posterior end of gravid female without protrusions or protrusions poorly developed. Cephalic end with or without large protrusions or papillae. Parasites of marine fishes ................................... 4 

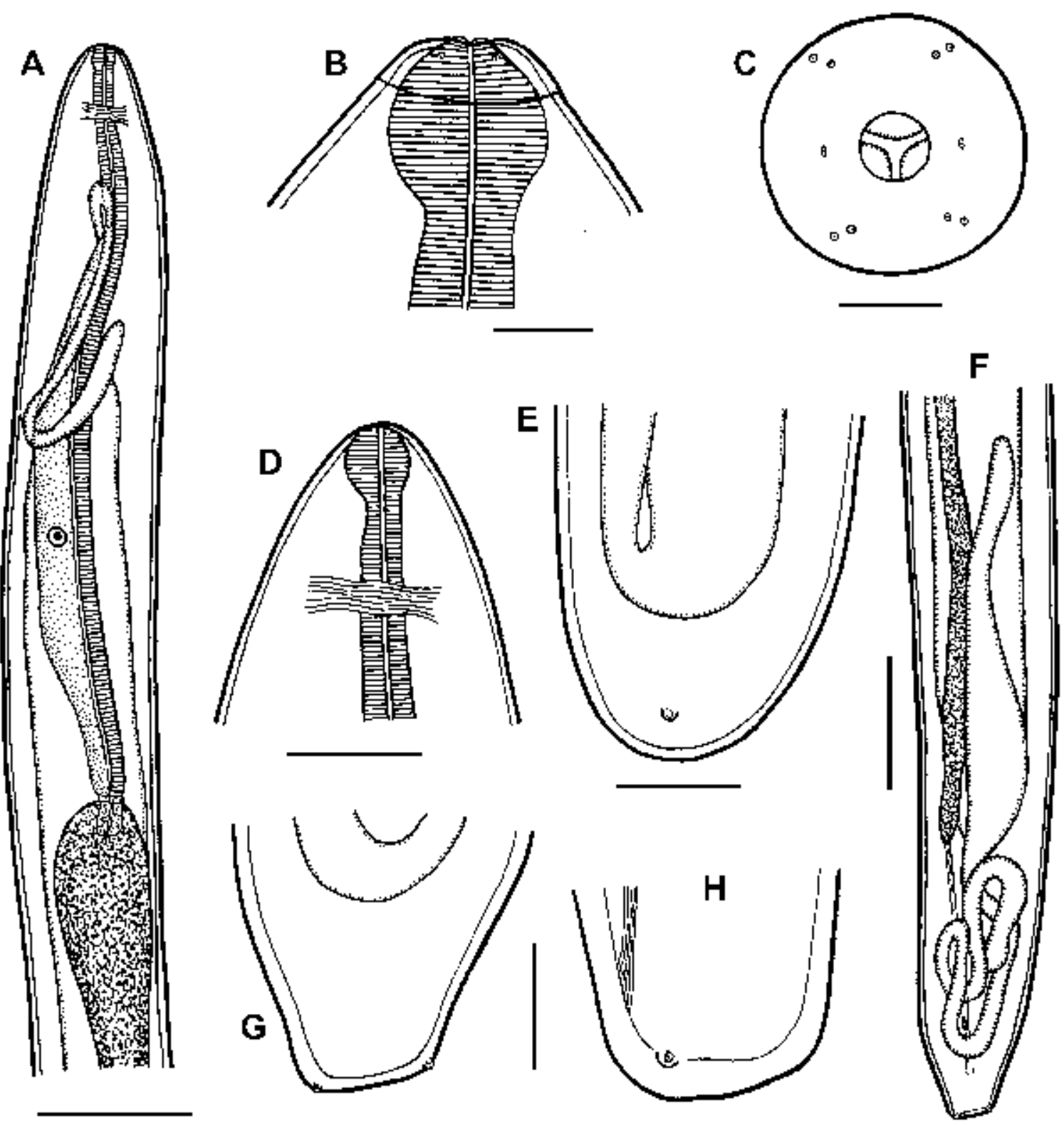

Fig. 3. Philometra tylosuri sp. n., nongravid female. A - anterior end of body; B, C - cephalic end, lateral and apical views; $\mathbf{D}$ - region of anterior part of oesophagus; $\mathbf{E}$ - caudal end, lateral view; $\mathbf{F}$ - posterior end, dorsoventral view; $\mathbf{G}, \mathbf{H}$ - caudal end (another specimen), dorsoventral and lateral views. Scale bars: $\mathrm{A}=300 \mu \mathrm{m} ; \mathrm{B}, \mathrm{E}, \mathrm{G}, \mathrm{H}=30 \mu \mathrm{m} ; \mathrm{C}=20 \mu \mathrm{m} ; \mathrm{D}, \mathrm{F}=100 \mu \mathrm{m}$.

2 Parasitic in African catfishes. Gravid female 20-31 mm long. Male unknown. In subcutaneous tissue of head and inner surface of operculum of Bagridae (Bagrus bajad); River Nile (Egypt, Sudan) P. bagri

- Parasitic in Palaearctic cyprinids .. 3

3 Gravid female 22-29 mm long, with dorsal cuticle bearing several inconspicuous, transverse needlelike structures. Length of oesophagus $1.6-1.7 \mathrm{~mm}$. Caudal protrusions papilla-like. Male unknown. In caudal fin of Cyprinidae (Oreoleuciscus); Central Asia (West-Mongolian lakes and Mountain Altai)
- Gravid female 30-42 mm long; cuticle without needle-like structures. Length of oesophagus 2.2$2.5 \mathrm{~mm}$. Caudal protrusions cone-shaped. Male 1.5-2.1 mm long; spicules almost equal, 45-57 $\mu \mathrm{m}$ and 45-53 $\mu \mathrm{m}$ long; gubernaculum $31-41 \mu \mathrm{m}$ long. Under skin of head, inner surface of operculum, mucosa of buccal cavity, and in fins of many species of Cyprinidae (Abramis, Alburnus, Aspius, Chalcalburnus, Chondrostoma, Leuciscus, Pseudaspius, Rutilus, Scardinius, Vimba); Europe and Palaearctic Asia 

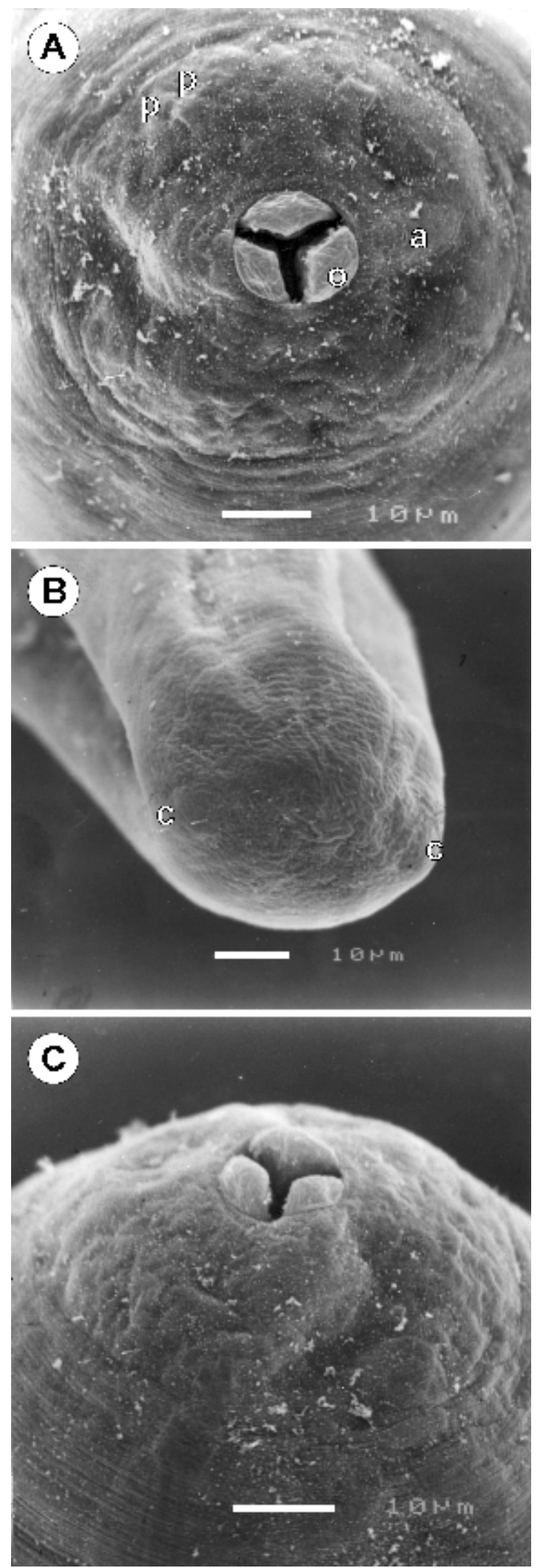

Fig. 4. Philometra tylosuri sp. n., scanning electron micrographs of nongravid female. A - cephalic end, apical view; B - cephalic end, subventral view; C - caudal end, apical view. Abbreviations: $\mathrm{a}$-amphid; $\mathrm{c}$-caudal projection; $\mathrm{o}$ - oesophageal projection; $\mathrm{p}$ - submedian cephalic papilla.
4 Gravid female small, 5-6 mm long. Length of oesophagus $0.24-0.27 \mathrm{~mm}$. Cephalic papillae indistinct. Male unknown. In pectoral fins of Sebastidae (Sebastes joyneri); Japan ............ P. sebastodis

- Body of gravid female at least $7 \mathrm{~mm}$ long. Length of oesophagus at least $0.8 \mathrm{~mm} \ldots \ldots \ldots \ldots \ldots \ldots \ldots . .5$

5 Body length of gravid female more than $100 \mathrm{~mm} .6$

- Body length of adult female less than $100 \mathrm{~mm}$.... 7

6 Gravid female more than $150 \mathrm{~mm}$ long. Eight small cephalic papillae of outer circle present. Anteriorly protruding oesophageal teeth present. Oesophagus $4.9 \mathrm{~mm}$ long. Male unknown. In subcutaneous tissue of unidentified fish ("large white fish"); Australia .................................. P. sydneyi

- Gravid female $135 \mathrm{~mm}$ long. Four distinct papillalike lobes, each with double cephalic papilla present. Oesophagus $3.3 \mathrm{~mm}$ long; oesophageal teeth absent. Male unknown. In subcutaneous tissue of marine Belonidae (Tylosurus gavialoides); Australia (Pacific Ocean) ......................... P. lomi

7 Gravid female with eight large cephalic papillae of outer circle; papillae of inner circle may be absent. Anterior oesophageal bulb large ................... 8

- Cephalic papillae very small, indistinct in lateral view. Anterior end of oesophagus moderately swollen ............................................ 11

8 Gravid female 7-16 mm long. Eight distinct cephalic papillae present. Oesophagus $0.8-1.0 \mathrm{~mm}$ long. Male unknown. In subcutaneous tissue of marine Plotosidae (Plotosus lineatus); Japan ........................................ P. plotosi

- Female at least $15 \mathrm{~mm}$ long. Parasites of fishes of other families ..................................... 9

9 Parasitic in Polydactylidae. Gravid female 20-35 $\mathrm{mm}$ long. Cephalic end with eight large, fleshy papillae of outer circle and four small single papillae of inner circle. Oesophagus $1.0 \mathrm{~mm}$ long. Male unknown. Subcutaneous tissue of head, in fins, and inner surface of operculum of Polydactylus quadrifilis; Eastern Central Atlantic (Nigeria)

\section{P. beninensis}

- Parasitic in Belonidae. Cephalic papillae of inner circle not observed 10

10 Gravid female 34-76 mm long. Cephalic papillae fairly large. Oesophagus representing 3-4\% of body length, with markedly large, transverse bulb at anterior end. Male unknown. In subcutaneous tissue of marine Belonidae (Tylosurus gavialoides); Australia (Pacific Ocean) P. kohnae

- Gravid female 15-20 mm long. Cephalic papillae markedly large. Oesophagus representing $9-11 \%$ of body length, with conspicuously large anterior bulb. Male unknown. Subcutaneous tissues, muscles of beak and gills of Strongylura leiura and S. strongylura; Persian Gulf, Iraq ........... P. strongylurae

11 Parasitic in Serranidae. Gravid female $22-40 \mathrm{~mm}$ long. Oesophagus 1.0-1.4 mm long. Male un- 
known. In fins of Epinephelus akaara; Inland Sea of Japan $P$. pinnicola

- Parasitic in Belonidae. Adult nongravid female 46$72 \mathrm{~mm}$ long. Oesophagus $1.6 \mathrm{~mm}$ long. Male unknown. Musculature and subcutaneous tissue of Tylosurus crocodilus; Persian Gulf, Iraq P. tylosuri

The two newly described species, Philometra strongylurae and $P$. tylosuri, are additional philometrid nematodes known to parasitize fishes of the family Belonidae (needlefishes). The only two other species are Philometra kohnae and P. lomi, both described from females found in the subcutaneous tissue of Tylosurus gavialoides (Castelnau) in Australia (Moravec and Rohde 1992). Although the morphology of $P$. strongylurae resembles that of $P$. kohnae and $P$. tylosuri somewhat resembles $P$. lomi, there are distinct morphological differences between them, as shown in the above key, and the pairs of species also differ in their hosts and geographical distributions.

In addition, two valid species of philometrids, Philometra globiceps (Rudolphi, 1819) and P. pellucida (Jägerskiöld, 1893), were reported from needlefishes, the former from Tylosurus acus (Lacépède) from Africa and the latter from Strongylura incisa (Valenciennes) from Australia and from Strongylura leiura and Xenentodon cancila (Hamilton) from India (see Rasheed 1965). However, the types of the species in question occur in hosts belonging to other fish orders (Perciformes and Tetraodontiformes), with a different localisation in the host. Considering the high degree of host specificity in philometrids and their species-characteristic tissue sites, it can be assumed that the reports of these nematodes in Belonidae were based on misidentifications; the provided descriptions of these nematodes are poor, not making it possible to determine their actual species appurtenance.

There are also records of Philometra sp. from Strongylura notata (Poye) and Tylosurus crocodilus; for example, Petersen et al. (1993) reported gravid females of Philometra sp. up to $18 \mathrm{~cm}$ long from the flesh of $T$. crocodilus in Philippine waters. Many years ago, the senior author (F. M.) of this paper examined two body fragments of the gravid female of Philometra sp. collected from the stomach of "Belone" sp. from the Gulf of Beresin, Red Sea, in 1892, deposited in the Museo Civico di Storia Naturale "G. Doria", Genova, Italy (unpublished). The body of the nematode was dark brown, about $950 \mathrm{~mm}$ long and $1.2 \mathrm{~mm}$ wide; the cephalic end was rounded, with minute cephalic papillae, and with two moderately developed papilla-like lateral caudal protrusions; the uterus was filled with numerous larvae.

Acknowledgements. The authors wish to thank the staff of the laboratory of Electron Microscopy, Institute of Parasitology, ASCR, in České Budějovice for their technical assistance, and to Irena Husáková, a technician of the Department of Helminthology of the same Institute, for her help with illustrations. This study was partly supported by the grant 524/03/0061 from the Grant Agency of the Czech Republic and the research project of the Institute of Parasitology, ASCR (no. Z60220518).

\section{REFERENCES}

FROESE R., PAULY D. (Eds.) 2004: FishBase. World Wide Web electronic publication. www.fishbase.org, version 07/2004.

IVASHKIN V.M., SOBOLEV A.A., KHROMOVA L.A. 1971: [Camallanata of Animals and Man and the Diseases Caused by Them. Osnovy nematodologii 22.] Nauka, Moscow, 388 pp. (In Russian.)

MORAVEC F. 2004: Some aspects of the taxonomy and biology of dracunculoid nematodes parasitic in fishes: a review. Folia Parasitol. 51: 1-13.

MORAVEC F., FIALA I., DYKOVÁ I. 2004: Philometra thaiensis sp. n. (Nematoda: Philometridae) from Tetraodon palembangensis and T. fluviatilis (Pisces) from fresh waters in Thailand, with a key to Philometra spp. parasitic in the host's abdominal cavity. Acta Parasitol. 49: 319324.
MORAVEC F., ROHDE K. 1992: Three species of nematodes of the superfamily Dracunculoidea from Australian fishes. Acta Soc. Zool. Bohemoslov. 56: 187-195.

MORAVEC F., SALGADO-MALDONADO G., AGUILARAGUILAR R. 2002: Two new nematodes, Paraseuratoides ophisterni gen. et sp. n. (Quimperiidae) and Philometra ophisterni sp. n. (Philometridae), from the swamp-eel Ophisternon aenigmaticum in Mexico. Folia Parasitol. 49: 109-117.

PETERSEN F., PALM H., MÖLLER H., CUZI M.A. 1993: Flesh parasites of fish from central Philippine waters. Dis. Aquat. Org. 15: 81-86.

RASHEED S. 1963: A revision of the genus Philometra Costa, 1845. J. Helminthol. 37: 89-130.

RASHEED S. 1965: Additional notes on the family Philometridae Baylis and Daubney, 1926. J. Helminthol. 39: 349362 .

Accepted 10 January 2005 